\title{
ANALISIS TINDAK TUTUR BAHASA KOMERING DESA TANJUNG BARU KECAMATAN TANJUNG LUBUK KABUPATEN OGAN KOMERING ILIR (SEBUAH KAJIAN PRAGMATIK)
}

\author{
${ }^{1}$ Yanti Sariasih, ${ }^{2}$ Rusfarita \\ ${ }^{1}$ AMIK AKMI Baturaja, Sumatera Selatan
}

\begin{abstract}
ABSTRAK
Tujuan penelitian ini bentuk dan jenis tindak tutur ilokusi bahasa Komering desa Tanjung Baru Kecamatan Tanjung Lubuk Kabupaten Ogan Komering Ilir berdasarkan kajian pragmatik ? Sampel dalam penelitian ini adalah remaja berusia 16 tahun berjumlah 30 orang. Teknik pengumpulan data yang digunakan peneliti dalam penelitian ini adalah teknik simak bebas libat cakap. Penelitian ini juga menggunakan teknik catat dan dibantu dengan teknik lanjutan berupa teknik rekam. Hasil penelitian ini adalah (1) Tindak tutur asertif bentuk mengklaim, mengeluh, menyatakan, jenis tindak tutur direktif bentuk bertanya, memerintah, meminta, jenis tindak tutur ekspresif bentuk pujian, mengkritik, rasa senang, jenis tindak tutur deklarasi bentuk pernyataan benar, tidak setuju, dan setuju. Jenis tindak tutur komisif tidak ditemukan dalam penelitian ini, hal tersebut disebabkan oleh situasi tutur. Situasi tutur pada saat peristiwa tutur berlangsung tidak mendukung atau mendorong penutur untuk melakukan tindak tutur yang akan melibatkan dirinya pada beberapa tindakan akan datang, misalnya berjanji, bersumpah, dan memanjatkan (doa). Berdasarkan analisis yang telah dilakukan, selain adanya tindak tutur ilokusioner dalam penelitian ini juga ditemukan jenis tindak tutur yang lain. Jenis tindak tutur yang ditemukan, yaitu tindak tutur lokusioner, tindak tutur tidak literal, dan tindak tutur tidak langsung.
\end{abstract}

Kata Kunci: Tindak tutur, Bahasa Komering, Pragmatik 


\section{A. Pendahuluan}

Bahasa mempunyai fungsi yang penting bagi manusia, terutama fungsi komunikatif (Tarigan, 2009:5). Bahasa merupakan salah satu budaya manusia yang sangat tinggi nilainya karena dengan bahasa manusia dapat berkomunikasi dan berinteraksi dengan masyarakat sekitar. Tanpa kehadiran bahasa, manusia tidak akan dapat saling berhubungan antara yang satu dengan lainnya. Kerja sama antarmanusia juga hampir mustahil dilakukan dengan optimal bilamana bahasa tidak benarbenar hadir sebagai peranti komunikasi dan interaksi.

Bahasa juga merupakan salah satu ciri yang membedakan manusia dengan makhluk sosial lain. Di dalam kehidupan bermasyarakat, sebenarnya manusia dapat menggunakan alat komunikasi lain selain bahasa, tetapi tampaknya bahasa merupakan alat komunikasi yang paling baik diantara alat-alat komunikasi lainnya. Apalagi bila dibandingkan dengan alat komunikasi yang digunakan makhluk sosial lain, yakni hewan. Bahasa dapat menimbulkan beberapa macam perbedaan antara pemakai bahasa, sesuai dengan kebudayaan dan daerah itu sendiri yang mempunyai ciri khas berbeda. Bahasa juga dapat mempengaruhi arah perilaku manusia. Bahasa daerah sebagai komponen budaya, merupakan bagian dari keberdayaan bangsa Indonesia yang hidup dan terus berkembang. Bahasa daerah merupakan aset kebudayaan Indonesia yang harus dijaga.

Fungsi dan kedudukan bahasa daerah sangat penting, sehingga di dalam UUD 1945, bab XV, pasal 36 berbunyi "Bahasa-bahasa daerah yang dipelihara oleh rakyatnya dengan baik akan dihormati dan dipelihara juga oleh negara", karena bahasa itu merupakan sebagian dari kebudayaan Indonesia yang hidup. Bahasa daerah penting pula untuk usaha dan program pengembangan, serta pembakuan bahasa nasional Indonesia. Dalam masa perkembangan dan pembangunan ini, bahasa daerah sangat diperlukan untuk memperkaya bahasa Indonesia terutama dalam kosa kata.

Bahasa daerah, termasuk juga bahasa Komering adalah salah satu kekayaan budaya Indonesia. Bahasa daerah dapat dimanfaatkan untuk mengembangkan bahasa nasional dan digunakan untuk kepentingan pembinaan bahasa Komering itu sendiri. Bahasa Komering adalah salah satu bahasa daerah yang terdapat di Indonesia juga merupakan pendukung keutuhan dan kesinambungan kehidupan kebudayaan Indonesia, oleh karena itu harus dilestarikan dan dijaga sebaik-baiknya agar tetap hidup dan berkembang.

Perkembangan tatanan baru kehidupan dunia dan teknologi informasi yang semakin sarat dengan tuntutan dan tantangan globalisasi telah mengondisikan dan menempatkan bahasa asing pada posisi strategis, memungkinkannya memasuki berbagai sendi kehidupan bangsa sekaligus mempengaruhi perkembangan bahasa Komering dengan mendesaknya dan memudarkannya. Hal itu pada akhirnya juga membawa perubahan perilaku masyarakat dalam bertindak dan berbahasa. Berbagai kata dan istilah dalam bidang ilmu pengetahuan dan teknologi biasanya tidak tersedia dalam kosakata bahasa daerah temasuk bahasa Komering. Hal itu merupakan salah satu sebab adanya anggapan bahwa bahasa asing diasosiasikan lebih maju atau modern.

Bahasa asing telah menggeser posisi bahasa daerah di Indonesia. Bahasa 
daerah dianggap ketinggalan jaman bagi sebagian masyarakat. Masuknya budaya asing tidak lepas dari peran media massa sebagai sumber informasi masyarakat. Media massa yang di dalamnya terdapat berbagai kepentingan, termasuk kepentingan pengiklanan telah menjadi agen pembawa kebudayaan global.

Terdapat kekurangan mengenai penggunaan bahasa Komering dalam masyarakat yang telah terpengaruh budaya global. Masyarakat, khususnya generasi muda jarang yang menggunakan bahasa Komering sebagai bahasa ibunya. Jarang juga dari mereka yang bisa berbahasa Komering, akibatnya penggunaan bahasa Komering sebagai bahasa percakapan sehari-hari (bahasa ibu) menjadi kurang efektif. Apalagi digunakan dalam dunia kerja di dalamnya terdapat orang-orang yang tidak hanya berasal dari suku Komering saja, maka bahasa Indonesia menjadi pilihan untuk berkomunikasi agar tidak terjadi hambatan dalam berkomunikasi, meskipun demikian bahasa daerah harus tetap dilestarikan karena bahasa merupakan hasil cipta, rasa, dan karsa manusia.

Pada suku Komering terdapat paling tidak dua ragam intonasi suara dalam berbahasa. Dialek suku Komering Marga Bengkulah akan terdengar cenderung berintonasi lebih datar, halus, dan tidak mendayu. Bahasa Komering Ulu intonasinya lebih tegas, tinggi, dan mendayu. Intonasi pengucapan dari penutur satu dengan yang lain bisa membedakan maksud dari tuturan. Hal tersebut menyebabkan suatu tuturan memiliki atau menghasilkan beraneka ragam tindak tutur yang menarik untuk diteliti.

Menurut Levinson (dalam Rahardi, 2009:20) "Pragmatik adalah studi bahasa yang mempelajari relasi bahasa dengan konteksnya". Dengan kata lain, pragmatik merupakan telaah mengenai kemampuan pemakai bahasa menghubungkan serta penyerasian kalimat-kalimat dan konteks-konteks secara tepat. Dalam sebuah ujaran untuk memahami makna yang dikehendaki penutur perlu memperhatikan konteks, sehingga komunikasi dapat berjalan dengan lancar. Apabila konteks tidak dipahami, maka akan terjadi kesalahpahaman yang mengakibatkan komunikasi tidak berjalan dengan lancar.

Parker (dalam Rahardi, 2009:21) menyatakan, "Pragmatik itu adalah cabang ilmu bahasa yang mempelajari struktur bahasa secara eksternal". Maksud hal tersebut adalah bagaimana sesungguhnya satuan lingual tertentu dapat digunakan dalam komunikasi yang sebenarnya. Pakar bahasa ini dengan tegas membedakan pragmatik dengan studi tata bahasa yang dianggapnya sebagai studi seluk-beluk bahasa secara internal, menurutnya studi tata bahasa itu tidak perlu dikaitkan dengan konteksnya. Berkenaan dengan hal itu, maka studi tata bahasa dianggap sebagai studi bahasa yang bebas konteks atau tidak terikat konteks, sebaliknya studi pemakaian tata bahasa dalam komunikasi sebenarnya mutlak dikaitkan dengan konteks situasi.

Pragmatik bertugas mengkaji maksud penutur dalam menuturkan satuan lingual tertentu pada sebuah praktik bahasa (Rahardi, 2009:21). Pragmatik dapat dikatakan sejajar dengan semantik yang juga mengkaji perihal makna. Perbedaan antar keduanya adalah bahwa pragmatik mengkaji makna menurut tafsiran pendengar, sedangkan semantik mengkaji makna kalimat. Semantik diatur oleh kaidah 
kebahasaan (tata bahasa), sedangkan pragmatik dikendalikan oleh prinsip komunikasi. Kajian makna dalam semantik lebih objektif daripada pragmatik karena hanya memperhatikan makna tersebut sesuai dengan makna yang terdapat dalam leksemnya. Kajian makna pragmatik dapat dikatakan lebih subjektif karena mengandung konteks atau memperhatikan konteks, dan setiap orang pasti mempunyai makna sendiri sesuai dengan konteks yang dipandangnya.

Berdasarkan beberapa pendapat di atas, secara garis besar definisi pragmatik tidak dapat lepas dari bahasa dan konteks. Dapat disimpulkan, bahwa pragmatik adalah salah satu cabang dari linguistik secara khusus mengkaji hubungan antara bahasa dan konteks yang mendasari penjelasan pengertian bahasa. Pengertian pemahaman disini menunjuk kepada fakta bahwa untuk mengerti suatu ungkapan ujaran diperlukan juga pengetahuan diluar makna kata dan hubungan tata bahasanya, yakni hubungannya dengan konteks pemakainya. Hal tersebut menyebabkan pendekatan pragmatik sangat relevan digunakan untuk mengungkap makna-makna tindak tutur yang berada dalam suatu konteks.

Chaer dan Agustina (2010:50) menjelaskan, "Tindak tutur merupakan gejala individual, bersifat psikologis, dan keberlangsungannya ditentukan oleh kemampuan bahasa si penutur dalam menghadapi situasi tertentu". Tindak tutur merupakan hal penting dalam kajian pragmatik. Tindak tutur merupakan telaah mengenai bagaimana cara kita melakukan sesuatu dengan memanfaatkan

kalimat-kalimat (Tarigan, 2009:31). Dalam menelaah tindak tutur kita harus menyadari betapa pentingnya konteks ucapan atau ungkapan. Teori tindak tutur adalah teori lebih cenderung meneliti makna dan maksud kalimat, bukan teori yang berusaha meneliti struktur kalimat (Aslinda dan Syafyahya, 2007:34). Apabila seseorang ingin mengemukakan sesuatu kepada orang lain, apa yang ingin dikemukakannya itu adalah makna atau maksud kalimat. Dalam menuturkan kalimat, seseorang tidak semata-mata mengatakan sesuatu dengan mengucapkan kalimat itu. Ketika ia menuturkan kalimat, berarti ia menindakkan sesuatu.

Penelitian ini relevan dengan penelitian yang dilakukan oleh Septy Silvia Sari (2012) dan Agus Setiaji (2014). Septy Silvia Sari (2012) dengan judul Analisis Tindak Tutur Penjual dan Pembeli di Pasar Satwa dan Tanaman Hias Yogyakarta (Kajian Pragmatik). Hasil yang didapat dari penelitian tersebut adalah (1) Bentuk tindak tutur yang ditemukan yaitu tindak tutur lokusi, tindak tutur ilokusi, dan tindak tutur perlokusi (2) Jenis tindak tutur yang ditemukan adalah lokusi pernyataan, lokusi perintah, lokusi pertanyaan, asertif, direktif, komisif, dan ekspresif.

Agus Setiaji (2014) dengan judul Analisis Tindak Tutur Bahasa Jawa di Pasar Sampang Kecamatan Sampang Kabupaten Cilacap. Hasil yang didapat dari penelitian tersebut adalah (1) Tindak tutur berdasarkan daya tutur yang dite mukan meliputi tindak tutur lokusi, ilokusi, dan perlokusi (2) Tindak tutur ilokusi yang ditemukan meliputi tindak tutur melapor, tindak tutur mendesak, tindak tutur menyarankan, dan tindak tutur mengumumkan (3) Tindak tutur perloksi meliputi tindak tutur membujuk, tindak tutur menjengkelkan, dan tindak tutur menarik perhatian (4) Fungsi ilokusi yang ditemukan yaitu tindak tutur 
asertif, tindak tutur komisif, tindak tutur direktif, dan tindak tutur ekspresif.

Berdasarkan latar belakang masalah, demi terwujudnya pembahasan secara terarah, maka dirumuskan masalah penelitian bagaimanakah bentuk dan jenis tindak tutur ilokusi bahasa Komering desa Tanjung Baru Kecamatan Tanjung Lubuk Kabupaten Ogan Komering Ilir berdasarkan kajian pragmatik ? tujuan penelitian ini untuk mendeskripsikan bentuk dan jenis tindak tutur ilokusi bahasa Komering desa Tanjung Baru Kecamatan Tanjung Lubuk Kabupaten Ogan Komering Ilir berdasarkan kajian pragmatik.

Metode penelitian yang digunakan dalam penelitian ini adalah metode kualitatif. Analisis kualitatif fokusnya pada penunjukan makna, deskripsi, penjernihan, dan penempatan data pada konteksnya masing-masing, serta seringkali melukiskannya dalam bentuk kata-kata daripada dalam angka-angka (Mahsun, 2012:257). Sumber data primer yang digunakan dalam penelitian ini adalah tindak tutur masyarakat desa Tanjung Baru. Sumber data sekunder adalah data yang bersumber dari sumber-sumber bacaan berhubungan dengan permasalahan objek penelitian. Dalam penelitian ini yang dijadikan populasi adalah seluruh warga masyarakat desa Tanjung Baru berusia 16 tahun berjumlah 30 orang. Jumlah laki-laki 15 orang dan jumlah perempuan 15 orang. Teknik pengumpulan data yang digunakan peneliti dalam penelitian ini adalah teknik simak bebas libat cakap.

\section{B. Pembahasan}

Tindak tutur ilokusioner (illocutionary act) yaitu, tindak tutur yang didefinisikan sebagai sebuah tuturan selain berfungsi untuk mengatakan atau menginformasikan sesuatu dapat juga digunakan untuk melakukan sesuatu. Tindak tutur ilokusioner ini merupakan tindak melakukan sesuatu dengan maksud dan fungsi tertentu dalam kegiatan bertutur yang sesungguhnya. Tindak tutur ilokusioner berkaitan dengan nilai yang ada dalam proposisinya. Searle (dalam Rahardi, 2009:17) mengelompokkan tindak tutur berdasarkan maksud penutur ketika berbicara (ilokusioner) menjadi lima jenis, yaitu tindak tutur asertif, direktif, komisif, ekspresif, dan deklarasi.

\section{Tindak Tutur Asertif}

Tindak tutur asertif, yaitu tindak tutur berfungsi mengikat penutur pada kebenaran proposisi yang sedang diungkapkannya dalam tuturan itu. Bentuk tutur asertif dapat mencakup hal-hal seperti, menyatakan (stating), menyarankan (sugesting), membual (boasting), mengeluh (complaining), dan mengklaim (claiming). Di bawah ini dikemukakan bebrapa contoh tutuan dalam bahasa Komering.

Pertama, tuturan "layon pok lampu titogak, pok tiang lampu sinaho" (bukan, tempat lampu jalan, tempat tiang lampu itu), disampaikan penutur dengan maksud untuk menyatakan bahwa tidak benar sebuah mobil yang dimaksud oleh mitra tutur telah menabrak tiang listrik melainkan lampu jalan. Tuturan tersebut termasuk dalam jenis tindak tutur asertif bentuk mengklaim, karena penutur mengatakan suatu fakta atau kebenaran. Kedua, tuturan "haos u nyak" (haus sekali saya), maksud dari tuturan tersebut adalah penutur menyatakan bahwa dirinya sedang haus dan ingin minum, karena melihat laki-laki yang sedang membawa botol air minum. Tuturan tersebut termasuk dalam tindak tutur asertif bentuk menyatakan, karena tuturan itu mengikat penutur pada kebenaran proposisi yang sedang 
diungkapkannya. Ketiga, tuturan "lamonga ciramah" (terlalu banyak ceramah), disampaikan penutur kepada mitra tutur dengan maksud untuk memberitahukan bahwa pemain sulap itu terlalu banyak bicara, sehingga penutur merasa bosan melihat atau menyaksikan pertunjukan sulapnya. Tuturan tersebut termasuk dalam jenis tindak tutur asertif bentuk mengeluh, karena tuturan itu mengikat penutur pada kebenaran proposisi yang sedang diungkapkannya.

\section{Tindak Tutur Direktif}

Tindak tutur direktif, yaitu tindak tutur berfungsi untuk membuat pengaruh agar mitra tutur melakukan tindakantindakan yang dikehendaki penutur, seperti meminta, bertanya, memerintah, dan lain-lain. Berikut ini adalah contoh tuturan dalam bahasa Komering.

Tuturan "mana ?" (mana ?), disampaikan penutur dengan maksud untuk menanyakan dimana mitra tutur melihat teman mereka. Tuturan itu termasuk dalam jenis tindak tutur direktif bentuk bertanya, karena selain menyatakan sesuatu juga berfungsi untuk membuat pengaruh agar mitra tutur melakukan tindakan yang dikehendaki penutur. Penutur mengekspresikan keinginan kepada mitra tutur, mitra tutur menjawab apa yang ditanya oleh penutur. Tuturan " $V i$, pira langsak mu ?" (Vi, berapa dukumu ?), disampaikan penutur kepada mitra dengan maksud untuk bertanya berapakah jumlah duku yang telah dijual oleh mitra tutur kepada pembeli duku. Jenis tindak tutur tersebut termasuk dalam tindak tutur direktif bentuk bertanya, karena selain menyatakan sesuatu juga berfungsi membuat pengaruh pada mitra tutur untuk melakukan tindakan yang dikehendaki penutur yaitu tindakan bertanya.
Tuturan "Mul sido liakpai !" (Mul itu lihat dulu !), disampaikan penutur kepada mitra tutur dengan maksud untuk memberitahukan bahwa di tempat pertunjukan sulap itu ada teman mereka. Tuturan itu termasuk dalam jenis tindak tutur direktif bentuk memerintah, karena selain menginformasikan juga mengandung tindakan menyuruh atau memerintah mitra tutur untuk melihat teman mereka.

\section{Tindak Tutur Komisif}

Tindak tutur komisif, yaitu tindak tutur yang berfungsi untuk mendorong pembicaraan melakukan sesuatu, seperti berjanji, bersumpah, dan memanjatkan (doa). Di dalam penelitian ini dari hasil rekaman yang diperoleh peneliti, setelah dianalisis ternyata tidak ditemukan jenis tindak tutur komisif, karena dari semua hasil rekaman tidak terdapat tuturan berfungsi untuk mendorong pembicaraan melakukan sesuatu, seperti berjanji, bersumpah, dan memanjatkan (doa).

\section{Tindak Tutur Ekspresif}

Tindak tutur ekspresif,tindak tutur yang berfungsi untuk mengekspresikan perasaan dan sikap. Tindak tutur ini berupa tindak meminta maaf, berterimakasih, menyampaikan ucapan selamat, memuji, dan mengkritik. Perasaan dan pengekspresian penutur untuk jenis situasi tertentu yang dapat berupa tindak penyampaian salam (greeting) mengekspresikan rasa senang, karena bertemu dan melihat seseorang, tindak berterimakasih (thanking) mengekspresikan rasa syukur, karena telah menerima sesuatu. Tindak meminta maaf (apologizing) mengekspresikan simpati, karena penutur telah melukai atau mengganggu mitra tutur. 
Tuturan "holauna $\mathrm{Hp} \mathrm{mu} \mathrm{anyar} \mathrm{yak"}$ (bagusnya Hpmu baru ya), disampaikan dengan maksud untuk memuji $H p$ yang dimiliki oleh mitra tutur. Tuturan tersebut termasuk dalam jenis tindak tutur ekspresif bentuk pujian, karena penutur mengekspresikan perasaan dan sikapnya bahwa dia menyukai $H p$ yang dimiliki oleh mitra tutur dengan pujian.

Tuturan "apia bak buoksa Rup, nipihdo liakpaina mimirangan" (bagaimana dengan rambutmu ini Rup, tipis ini lihatlah dulu pirang), disampaikan penutur kepada mitra tutur dengan maksud untuk mengejek rambut mitra tutur yang tipis dan berwarna kemerahmerahan. Tuturan tersebut termasuk dalam jenis tindak tutur ekspresif bentuk mengkritik, karena selain mengatakan sesuatu juga mempunyai maksud untuk mengkritik.

Tuturan "kuhujanan sikamna jona ya, nah ngaman dimusigid rik wali kelasku ratong tipopak" (kehujanan kami itu tadi ya, nah berteduh di masjid dengan wali kelasku tiba-tiba ketemu), disampaikan penutur kepada mitra tutur untuk mengekspresikan rasa senang secara tidak sengaja bertemu dengan wali kelasnya saat berteduh di masjid karena kehujanan. Tuturan tersebut termasuk dalam jenis tindak tutur ekspresif bentuk mengekspresikan rasa senang.

\section{Tindak Tutur Deklarasi}

Tindak tutur deklarasi, yaitu tindak tutur berfungsi untuk memantapkan sesuatu yang dinyatakan, antara lain dengan setuju, tidak setuju, benar-benar salah, dan sebagainya. Berikut ini hasil tuturan dalam bahasa Komering yang menunjukkan tindak tutur deklaratif.

Tuturan “ $m$ " (уа), maksudnya adalah penutur membenarkan pernyataan bahwa foto yang akan dicuci berada di folder image. Tuturan tersebut termasuk dalam jenis tindak tutur deklarasi bentuk pernyataan benar, karena selain untuk mengatakan sesuatu tuturan itu juga memantapkan sesuatu yang dinyatakan.

Tuturan "ne kan" disampaikan penutur kepada mitra tutur dengan maksud untuk menyatakan bahwa dia tidak setuju jika teman mereka yang rumahnya jauh tidak perlu datang ke tempat itu, menurutnya hal wajar jika temannya berada disitu untuk menyaksikan pertunjukan sulap. Tuturan tersebut termasuk dalam jenis tindak tutur deklarasi bentuk pernyataan tidak setuju, karena selain untuk mengatakan sesuatu tuturan itu juga memantapkan sesuatu yang dinyatakan dengan tidak setuju.

Tuturan "Tahu, batang langsak lamon bangat, marik wat pocong" (batang duku banyak sekali, nanti ada pocong), disampaikan penutur kepada mitra tutur dengan maksud menyatakan bahwa untuk sampai pada tempat pertunjukan sulap itu, teman mereka harus melalui pohon duku yang banyak dan jalan gelap, jadi penutur tidak setuju jika teman mereka datang ke tempat itu. Tuturan tersebut termasuk dalam tindak tutur deklarasi bentuk tidak setuju, karena selain untuk mengatakan sesuatu tuturan itu juga memantapkan sesuatu yang dinyatakan.

Tuturan " $m$ " (ya), disampaikan penutur kepada mitra tutur dengan maksud untuk memantapkan pernyataan setuju bahwa dia mau menemani mitra tutur untuk mencari jualan ikan. Tuturan tersebut termasuk dalam jenis tindak tutur deklarasi bentuk setuju, karena selain untuk mengatakan sesuatu tuturan itu juga memantapkan sesuatu yang dinyatakan dengan setuju. Selain jenis tuturan yang telah dipaparkan 
sebelumnya, ternyata selain adanya tindak tutur ilokusioner juga terdapat tindak tutur lokusioner, tindak tutur tidak literal, dan tindak tutur tidak langsung.

\section{Tindak Tutur Lokusioner}

Tindak tutur lokusioner atau apa yang dikatakan (locutionary act) adalah tindak tutur untuk menyatakan sesuatu. Misal, kakinya dua, pohon punya daun. Tindak tutur yang dilakukan oleh penutur berkaitan dengan perbuatan dalam hubungannya tentang sesuatu dan mengatakan sesuatu (an act of saying something). Tindak tutur lokusioner ini disebut dengan istilah tindak bahasa preposisi, karena hanya berkaitan dengan makna.

Tuturan "sikam mbija dijasa lamonna sikam liak" (kami kemarin disini banyak sekali kami lihat), disampaikan penutur kepada mitra tutur dengan maksud menginformasikan kepada mitra tutur bahwa kemarin di kebun itu banyak sekali buah duku yang jatuh. Tuturan tersebut adalah termasuk jenis tindak tutur lokusioner, karena penutur hanya menginformasikan saja tentang kenyataan tanpa mengandung maksud atau tujuan.

Tuturan "na, Mat husin rik nggomanna" (itu Mat husin dengan istrinya), disampaikan penutur kepada mitra tutur untuk menginformasikan kepada mitra tutur bahwa Mat husin dengan istrinya sedang lewat bermotor. Tuturan di atas adalah tindak tutur lokusioner, karena penutur hanya menginformasikan saja tentang kenyataan tanpa mengandung maksud atau tujuan.

Tuturan "ha disuahna lah bakas sinaho kurabaian ya" (hendak dibakarnya oleh laki-laki itu ketakutan dia), disampaikan penutur kepada mitra tutur dengan maksud untuk memberitahukan bahwa ada seseorang yang ketakutan karena ingin dibakar oleh pemain sulap. Tuturan tersebut termasuk dalam jenis tindak tutur lokusioner, karena hanya berfungsi untuk menginformasikan saja tanpa mengandung maksud atau tujuan.

\section{Tindak Tutur Tidak Literal}

Tindak tutur tidak literal adalah tindak tutur maksudnya tidak sama atau bahkan berlawanan dengan makna kata-kata yang menyusunnya. Contoh tuturan "solop holau putuk" (sandal bagus putus), maksud dari tuturan tersebut selain untuk menyatakan sesuatu juga berfungsi untuk mengejek atau menyindir sandal yang digunakan oleh temannya. Tuturan tersebut termasuk dalam tindak tutur tidak literal, karena ketika penutur menyampaikan tuturan itu bukan untuk menyatakan pujian melainkan mengejek atau menyindir mitra tutur.

\section{Tindak Tutur Tidak Langsung}

Tindak tutur tidak langsung adalah tindakan yang tidak dinyatakan langsung oleh modus kalimatnya. Untuk menyampaikan maksud memerintah orang bisa menggunakan kalimat berita atau bahkan menggunakan kalimat tanya. Berikut ini diberikan contoh tutuan tidak langsung dalam bahasa Komering.

Tuturan "kusikanmu wat mak ?" (korek apimu ada tidak?), disampaikan kepada mitra tutur dengan maksud atau tujuan meminjam korek api. Jenis tuturan di atas termasuk dalam jenis tindak tutur tidak langsung, karena untuk menyampaikan maksud memerintah mitra tutur memberikan atau meminjamkan korek api, penutur menggunakan kalimat tanya. 
Tuturan "sa duit" (ini uang), tuturan tersebut termasuk dalam jenis tindak tutur tidak langsung, karena penutur bukan hanya menginformasikan saja bahwa itu adalah uang, tetapi juga mengharapkan respon dari mitra tutur agar mengambil uang yang ditaruhnya di atas tangga, sebagai upah dari memetik duku.

Tuturan "liakpai na alangkok tihamparnana !" (lihatlah dulu itu alangkah terhamparnya), disampaikan penutur dengan maksud agar mitra tutur segera mewadahi duku. Tuturan tersebut termasuk dalam jenis tindak tutur tidak langsung, karena selain berfungsi memberitahukan bahwa banyak buah duku terhampar yang belum dimasukkan ke dalam peti juga berfungsi untuk mengekspresikan keinginan penutur kepada mitra tutur agar segera mewadahi duku tersebut ke dalam peti.

Tuturan "kok haga mulang ida" (sudah ingin pulang ida), disampaikan penutur kepada mitra tutur dengan maksud ingin mengajak temannya untuk pulang dari tempat pertunjukan sulap. Tuturan tersebut termasuk tindak tutur tidak langsung, karena dari sisi modusnya tuturan tersebut adalah kalimat berita, tetapi yang dimaksud oleh penutur yaitu mengajak atau memerintah temannya untuk pulang.

Tuturan "liakpai ina ri alangkok tihamparnana" (lihat dulu itu ri alangkah terhamparnya), disampaikan penutur kepada mitra tutur dengan maksud memerintahkan kepada mitra tutur untuk mengumpuli buah duku yang terhampar. Tuturan tersebut termasuk dalam jenis tindak tutur tidak langsung, karena selain menginformasikan banyaknya buah duku yang terhampar juga bermaksud untuk memerintah mitra tutur mengumpuli atau mewadahi buah duku tersebut.

\section{Simpulan}

Berdasarkan hasil analisis tindak tutur bahasa Komering desa Tanjung Baru Kecamatan Tanjung Lubuk Kabupaten Ogan Komering Ilir pada remaja usia 16 tahun, diketahui terdapat jenis tindak tutur ilokusioner. Jenis tindak tutur ilokusioner yang ditemukan, yaitu tindak tutur asertif bentuk mengklaim, mengeluh, menyatakan, jenis tindak tutur direktif bentuk bertanya, memerintah, meminta, jenis tindak tutur ekspresif bentuk pujian, mengkritik, rasa senang, jenis tindak tutur deklarasi bentuk pernyataan benar, tidak setuju, dan setuju. Jenis tindak tutur komisif tidak ditemukan dalam penelitian ini, hal tersebut disebabkan oleh situasi tutur. Situasi tutur pada saat peristiwa tutur berlangsung tidak mendukung atau mendorong penutur untuk melakukan tindak tutur yang akan melibatkan dirinya pada beberapa tindakan akan datang, misalnya berjanji, bersumpah, dan memanjatkan (doa).

Lebih lanjut, selain adanya tindak tutur ilokusioner dalam penelitian ini juga ditemukan jenis tindak tutur yang lain. Jenis tindak tutur yang ditemukan, yaitu tindak tutur lokusioner, tindak tutur tidak literal, dan tindak tutur tidak langsung. Hasil analisis pada tindak tutur lokusioner menunjukkan, bahwa penutur menggunakan tindak tutur ini untuk menyatakan atau menginformasikan kepada mitra tutur tentang suatu kenyataan tanpa mengandung maksud atau tujuan. Dalam penelitian ini ditemukan tindak tutur tidak literal, penutur menggunakan tindak tutur tersebut pada saat mengejek atau menyindir mitra tutur. Untuk menyampaikan maksud memerintah penutur juga bisa 
menggunakan tindak tutur tidak langsung, yaitu dengan kalimat berita bahkan menggunakan kalimat tanya agar mitra tutur atau orang yang diperintah tidak merasa diperintah.

\section{DAFTAR PUSTAKA}

Aslinda dan Syafyahya. 2007. Pengantar Sosiolinguistik. Bandung: PT Refika Aditama.

Chaer dan Agustina. 2010. Sosiolinguistik. Jakarta: Rineka Cipta.

Mahsun. 2012. Metode Penelitian Bahasa. Jakarta: PT Raja Grafindo Persada.

Moleong. 2004. Metodologi Penelitian Kualitatif. Denpasar: Pustaka Pelajar.

Rahardi, Kunjana. 2009. Sosiopragmatik. Yogyakarta: PT Gelora Aksara Pratama.

Sari. 2012. Analisis Tindak Tutur Penjual dan Pembeli di Pasar Satwa dan Tanaman Hias Yogyakarta (Kajian Pragmatik). Skripsi. Yogyakarta: Pendidikan Bahasa dan Sastra Indonesia, Fakultas Bahasa dan Seni, Universitas Negeri Yogyakarta.

Setiaji, Agus. 2014. Analisis Tindak Tutur Bahasa Jawa di Pasar Sampang Kecamatan Sampang Kabupaten Cilacap. Skripsi. Purworejo: Pendidikan Bahasa dan Sastra Jawa, Universitas Muhammadiyah Purworejo.

Tarigan. 2009. Pengajaran Pragmatik. Bandung: Angkasa. 